\title{
MYD88 wt Allele
}

National Cancer Institute

\section{Source}

National Cancer Institute. MYD88 wt Allele. NCI Thesaurus. Code C90095.

Human MYD88 wild-type allele is located in the vicinity of 3p22 and is approximately $5 \mathrm{~kb}$ in length. This allele, which encodes myeloid differentiation primary response protein MyD88, plays a role in both protein-protein interactions and the regulation of the expression of proinflammatory genes. Mutation of the gene is associated with recurrent pyogenic bacterial infections. 